\title{
Directions for applying profiling in the activity of a lawyer
}

\author{
Bella Psareva ${ }^{1, *}$, and Alexandra Gamayunova ${ }^{1}$ \\ ${ }^{1}$ Altai State University, 656049, 61a Lenina ave., Barnaul, Russia.
}

\begin{abstract}
In the article, various models (directions) of profiling are considered with the purpose of creating a psychological profile in the sphere of application of its technics in activity of a lawyer. The authors come to the conclusion that despite the fact that profiling has its own specifics in each of the directions, but since lie is a ubiquitous phenomenon and occurs in all spheres of human activity, non-instrumental diagnosis of lies finds application in any of them, which allows us to state about the universal character of profiling.
\end{abstract}

\section{Introduction}

The complex, universal, and integrated nature of profiling is currently confirmed by the presence in foreign and domestic experience of various profiling models (directions), having a different additional goal of creating a psychological profile and the scope of application of its techniques in the activity of a lawyer [1].

The directions of profiling remind the structure of the directions of the discipline of legal psychology: 1) criminological (preventive) psychology: lawful conduct (penitentiary), terrorism, extremism, riots, violence, aggression, cruelty; 2) criminal psychology: criminal environment and criminal communities/groups, criminal (deviant) behavior, typology of criminals' personalities; 3) the psychology of the Russian types of judicial proceedings: (f) pre-trial (investigator activities, support of operational and official activities, other participants in criminal litigation, complex forensic psycho-psychiatric examinations), (b) trial (judicial investigation, debate and speech, evaluation of court results of forensic psychological examination).

\section{Main directions of applying profiling in the activity of a lawyer}

1. The criminal-legal direction (law enforcement activity of employees of special services and law enforcement bodies).

Preventive-criminological (operational-search). The goal is the prevention of preparing crimes (preventive measures) and ensuring security (on transport, public, personal, etc.). There is an "operative triad": warning - prevention - suppression. Types included in this area may and may not involve contact with the observed person:

* Corresponding author: sofex_co@mail.ru 
Transport, operational profiling: the technology of preflight inspection in the customs control zone to identify potentially dangerous and aggressive persons who are carrying criminal intentions and preparing for a crime with the aim of causing harm to an unlimited number of persons and from whom one can expect illegal behavior at airports, railway stations, etc. The aim is to predict behavior for the prevention of illicit trafficking in prohibited items by special means of concealment when importing/exporting to/from the territory of the Russian Federation, crossing the border with the state and customs border by air, rail, and road [3]. Profiling developed and accumulated a theoretical and practical basis, began to acquire new aspects and scientific directions and to integrate into various spheres of human life (including professional activities) from the operational and preventive sphere.

Mass, territorial profiling [4, 5]. The police are obliged to ensure law and order in public places and to prevent terrorist acts in places of mass visits, congestion, and stay of citizens [6] by performing their duties, combating offenses that infringe upon these objects, and applying various measures of influence on offenders [7].

Penitentiary profiling in correctional facilities. The goal is to communicate with the convicts/detainees in order to organize correctional and educational influence, with the aim of ensuring the order of serving the sentence and stay in custody, organizing the execution of convicts and prisoners, detecting, preventing and eliminating the source of threats to the functioning and livelihoods of the correctional institution, etc. The lies of the convicts are aimed at obtaining benefits, relaxation in the regime, or transfer to more comfortable conditions of detention [8]. In the process of individual preventive work with every convict, psychologists are involved in conducting operational psychodiagnostics. The subject is the definition of the propensity to a particular crime [9]. Post-penitentiary profiling is an assessment of the effectiveness of measures of influence applied to a specific person, predicting behavior after being released from correctional fascilities.

2. The criminal-procedural direction has a goal of ensuring an effective investigation of already committed crimes [10].

Forensic profiling is operational search activities and drafting a legally significant document on the psychological portrait and the behavior of an unknown criminal and victim. This type of profiling also focuses on the analysis of activities in the form of necessary information, as well as on tracing a crime scene at the stage of organizing a preliminary investigation that could help in his/her capture. Methodology includes direct work with the criminal case materials and interpretation of evidence in the criminal case related to the investigation of the Ministry of Internal Affairs, the Federal Security Service, and the Investigative Committee of the Russian Federation. The purpose of the profiler's work is to search and identify the involved persons.

Judicial-forensic profiling. Recently, the concept of profiling was extended to the production of separate investigative cases [11]. The difference from forensic profiling is in a purposefully designed set of methodology and tactical and psychological techniques, combinations, the object of work, resulting in a psychological portrait being a concrete, visible, known person (a suspect, accused, victims and witnesses, experts, eyewitnesses, etc.). The goal is to build an effective tactic for the production of diabetes, an assessment of the reliability of the indications.

3. The civil-procedural direction: various areas of economic activity for securing the circle of communication in the commercial sector, etc.

Commercial profiling. This is a specific kind of interpersonal communication and interaction in the field of business management, the support of business negotiators by professional profilers (verifiers), supporting civil-law major transactions, contributing to the resolution of economic disputes, the mediation of corporate disputes, and preparation for arbitration proceedings. The goal is to act on the basis of the compiled picture in order to reduce risks in business $[12,13]$. 
Insurance and audit profiling. Companies and insurers are related to verifying the reliability of information, making decisions on the safe issuance of loans, identifying fraudulent schemes.

Profiling in the work of banks. The goal is to minimize losses when issuing bank loans, to prevent the loss of financial resources at the stage of considering an application for a loan and in a small interview with a borrower. A profiler helps to reduce losses to financiers. In companies where commercial profiling is used, fraud was not documented. More than that, a significant number of fraudulent activities and persons potentially dangerous for business were identified [14, 15].

Family disputes, includingttreason, fictitious marriage, embezzlement within the family, etc.

Personnel profiling (often in commerce) is applicable in the sphere of labor relations, especially when hiring employees: selection, verification, placement, rotation of staff.

Internal audit for leading international and local clients, profiles and recommendations are developed to predict the behavior of the audited persons, conduct interviews, etc.

3. The state-legal direction: political psychodiagnostics, drawing up a political portrait of politicians in the sphere of state policy, international law and security. The goal is to analyze a political situation in the conduct of political, economic, business negotiations (including diplomatic ones, with foreign partners), identify undesirable moments, make a typology of the opponent's behavior, as well as to oppose to manipulations. Methods of instant analysis are used, such as observation and physiognomic analysis [16].

4. Everyday reality/personal life. People are not used to talking about their shortcomings. No one will say right away that there are bad habits. Every person strives to seem good and pleasant to make a positive impression. But it takes on a serious turn when people hide something important about themselves, for example, destructive, dangerous features of their behavior.

\section{Conclusion}

Thus, each direction of profiling has its own specifics, but since a lie exists in all spheres of human activity, it presupposes the presence of hidden information in various forms (passive, active) in each direction. Consequently, a non-instrumental diagnosis of lies finds application in all of them. In the case of psychology in everyday or any professional activity, profiling acquires a specific form, according to situations, subjects, the nature of interaction and communication, but retains its psychological, psycho-diagnostic essence and methodology, as well as the overall process of psychological evaluation of a person as a whole.

\section{References}

1. V. A. Kudin, V. M, Statnyi, Bulletin of the St. Petersburg University of the Ministry of Internal Affairs of Russia, 59, 3 (2013)

2. Yu. N. Volynsky-Basmanov, N. D. Eriashvili, Profiling (Yuniti-Dana, Moscow, 2012)

3. R. V. Gonnov, V. N. Lyashenko, Collected materials of the VIII Inter-University Scientific and Practical Conference (Agruz, Stavropol, 2015)

4. MDA RF, Order of the Ministry of Internal Affairs of the Russian Federation of 28.01.2008 №80 (Ministry of Domestic Affairs, Moscow, 2008)

5. Government of Russia, Resolution of the Government of the Russian Federation No. 272 of March 25, 2015 (Government of the Russian Federation, Moscow, 2015) 
6. V. V. Zagainov, The use of visual psychodiagnostics for the recognition of persons of operational interest (East Siberian Institute of the Ministry of Internal Affairs of the Russian Federation, Irkutsk, 2017)

7. ConsultantPlus, On the Police: Federal Law of 07.02.2011 № 3 (ConsultantPlus, Moscow, 2017)

8. S. A. Tarasova, Bulletin of the Samara Juridical Institute, 9, 1 (2013)

9. S. E. German, The Science Vector of TSU - Series: Juridical Sciences, 29, 2 (2017)

10. V. O. Karpov, Bulletin of the Kazan Law Institute of the Ministry of Internal Affairs of Russia, 27, 1 (2017)

11. E. I. Voigel, A. A. Kozuleva, Siberian Criminal Procedural and Criminalistic Readings, 8, 22 (2017)

12. A. Yu. Kalabin, I. V. Kutuzov, The Bulletin of the Air Defense Concern Almaz-Antei, 8, 2 (2012)

13. T. Yu. Bazarov, R. M. Kutuev, Motivation and Remuneration of Labor, 3 (2016)

14. T. G. Martseva, Bulletin of the Academy of Knowledge of the Novorossiysk Branch of the Krasnodar University of the Ministry of Internal Affairs, 3, 3 (2012)

15. T. G, Martseva, Society and Law, 48, 2 (2014)

16. E. P. Sivkova, Complex Problems of Modern Politics, 2, 4 (2014) 